\title{
Experiences of mothers of children with Down syndrome
}

\author{
DEWI ELIZADIANI SUZA A, C-E, MARIA ANESTESIA NAPITUPULUA, B, HARIATI HARIATIE, F \\ ORCID ID: 0000-0002-6452-4773
}

Faculty of Nursing, Universitas Sumatera Utara, Medan, Indonesia

A - Study Design, B - Data Collection, C - Statistical Analysis, D - Data Interpretation, E - Manuscript Preparation, F - Literature Search, G - Funds Collection

Summary Background. Down syndrome is a genetically occurring chromosomal abnormality, characterized by mild to moderate intellectual impairment, difficulties in verbal and non-verbal communication, as well as disruption in social interactions. In addition, mothers of affected children possess various emotional experiences and must have strategies to provide optimal care in the face some physical and social challenges.

Objectives. The aim of this study was to describe the experiences of mothers of children with Down syndrome.

Material and methods. This was a qualitative research with a phenomenological approach, and the participants consisted of 10 mothers selected through purposive sampling. In addition, the study was conducted in Binjai, Indonesia, from April to May 2018. Data collection was performed using in-depth interviews with voice recording. Content analysis was adopted using the Collaizi method, and the principle of trustworthiness was subsequently applied.

Results. A total of 5 themes were recognized, including 1) having an emotional experience, 2) accepting the child's situation, 3) meeting the needs of children, 4) experiencing obstacles in caring for children and 5) expectation of the mother.

Conclusions. The study, based on the experiences of mothers of children with Down syndrome, provides important information for families, health workers and the health service system to enhance understanding of the condition, as well as the appropriate handling techniques. Furthermore, it is also necessary to further investigate the experiences of positive emotions in affected mothers.

Key word: child, Down syndrome, emotions, mothers.

Suza DE, Napitupulu MA, Hariati H. Experiences of mothers of children with Down syndrome. Fam Med Prim Care Rev 2020; 22(4): 338-342, doi: https://doi.org/10.5114/fmpcr.2020.100445.

\section{Background}

Down syndrome is a chromosomal disorder associated with distinctive facial shapes and mental retardation, with a prevalence of around $8 \%$ of all congenital abnormalities in Europe [1]. However, the predominance among children aged 4 years in the USA as of 2010 was around $12.7 \%$ in 10,000 [2], while a research on the Colombian population showed an incidence of 16.3 to $17.8 \%$ in every 10,000 live births. This manifestation was highly common with women over 35 years of age, in 40 out of 10,000 live births, and 120 out of 10,000 for those over 40 years of age [3].

A child affected with Down syndrome possesses limited abilities, especially in academics and during the conduct of daily activities. The physical and mental barriers also make it difficult for the parents and families to accept circumstances [4]. This situation leads to an initial feeling of shock, especially by the mother, as well as a very large change in mood, as most tend to require additional income to pay for additional therapy [5]. The support received from the surrounding environment has an effect, including the provision of positive social backings, which increases enthusiasm in parenting, strength, the feeling of calmness and not being underestimated and ostracized [6].

Mothers tend to experience relatively higher levels of fatigue than fathers, because they spend more time with the child. In addition, the most common problems in families include thoughts related to future prospects and the demand for more financial, social and spiritual support to accept the health condition. However, the forms of acceptance by parents include calming down, praying and learning to be more patient while facing everyday life [7].

Mothers of children with Down syndrome face several obstacles with varying degrees of difficulty. These include the quest for possible treatment and teaching the child independence with the hope of a better condition in the future. According to Lyons et al., the maternal deterrent factor in providing care for affected children is the factor of the child, the attitudes and views of others, as well as environmental and logistical problems [8]. In Indonesia, the possible obstacles include the limited knowledge, attitudes and negative views of the social environment, limitations in therapy, the incidence of less stable physical and mental conditions in mothers [9] and rejection by individuals within the residence, as well as some family members [10]. Alwhaibi and Aldugahishem identified some limitations with the presence of intellectual and communication disorders in children, which affects participation with others, busy mothers, rejection by children from the surrounding environment and lack of specifically designed facilities for those with disabilities, subsequently serving as a barrier to physical activity [11].

Some of the obstacles faced by children with Down syndrome in the health care system include unfair treatment or discrimination by health services. According to Ali et al., staff attitudes and behaviors were negative, leading to failures in providing reasonable services and status differences [12], as health workers rarely communicated with affected individuals in the correct manner [13]. The lack of support and care, as well as inappropriate policies, also become obstacles in caring for children with special needs in developing countries [14].

Cultural beliefs also greatly influence the perception of mothers and family members of children with Down syndrome. Riany et al. demonstrated how mothers in Indonesia hold on to the cultural beliefs of maternal behavior during pregnancy, karma and God's plan. However, some reported on the degree of pain felt after the positive diagnosis of their children, while some cultures attributed this manifestation as a curse for the family 
[15]. According to Mathebane, some mothers feel sadness and pain with this development, hence the desire to cry, which is often not fulfilled, as crying for a living person is assumed to be a taboo in the culture. This is only allowed when mourning for death. There is also a belief among black Africans that crying for a living person causes premature death [16]. Ahmed et al. identified ambivalent cultural stereotypes which characterized Down syndrome as an abnormal object, pity, closer to God and as a provider of luck. However, some support having an abortion in order to evade the experience of social stigmatization. The results of this study reveal how parents negotiate religious beliefs with personal experience to rationalize personal views on abortion resulting from a positive diagnosis [17].

Being born with Down syndrome does not mean a total inability to develop abilities, hence the presence and acceptance of parents to the child's condition is very important. This is because of the high dependence of children to meet their daily needs and activities [18], especially in the provision of care, by ensuring knowledge acquisition in an educational center [19].

Having a child with Down syndrome is an experience rarely possessed by parents. However, the condition features feelings of sadness, anger, inability to accept the situation and anxiety, burdens for mother in living and caring for their children. Therefore, it is important to deeply explore the experiences of mothers of children with Down syndrome.

\section{Objectives}

The aim of this study was to describe the experiences of mothers of children with Down syndrome.

\section{Material and methods}

\section{Study design}

This phenomenology study focused on a person's experience, which was converted into action; hence, the approach was expected to obtain a deep understanding of the experience of mothers of children with Down syndrome.

\section{Sample/participant}

The participants consisted of 10 mothers of children with Down syndrome, selected with purposive sampling. Participation criteria included: 1 ) the characteristic of being communicative and 2) the willingness to participate, which was declared verbally or by signing a research agreement.

\section{Data collection}

The study was conducted between April and May 2018 in Binjai, Indonesia. In addition, the data collection process was conducted by in-depth interviews using voice recording, where probing techniques were adopted to obtain comprehensive information. Furthermore, semi-structured interviews consisting of 6 open questions developed by the researcher, were used, which included the following: 1) How did you feel about having a child with Down syndrome? 2) What were your daily behaviors or activities? 3) How did mothers provide care to affected children? 4) What obstacles have been experienced in the process? 5) How did mothers face these challenges? 6) What were your hopes for your child?

The interview process was initiated by approaching the prospective participants through prolonged engagements to foster mutual trust and comfort and was followed by a contract of agreement with the respondent. This was performed in 2-3 meetings featuring the self-introduction of researchers and providing an explanation about the study aims and objectives. Therefore, the participants were asked for willing to be interviewed through the request to read and sign an informed consent along with the assurance of anonymity and confidentiality. The interview duration was 50-60 minutes, and data collection was terminated when no new information was obtained, as well as in instances of redundancy (saturation).

\section{Data analysis}

The data collected was evaluated using the Collaizi content analysis method. The steps taken included: (1) reading and copying all transcripts to make sense and meaning of the expressions by patients; (2) extracting significant research statements that are directly related to the research phenomena; (3) outlining the meaning contained, which are then combined and formulating into a theme; (4) integrating the results in the form of a complete theme description, is then formulated for the phenomenon; and (5) the participants are further re-validated. Member checking has been carried out to ensure that the researchers have analyzed the data correctly.

\section{Trustworthiness}

The principle of trustworthiness was applied to ensure credibility in research, which was a criterion to fulfill the truth value of the data and information collected. Hence, prolonged engagements were conducted by holding meetings with participants 2-3 times in designated places in order to foster a relationship and familiarity between the researcher and participants, alongside better openness and trust. Furthermore, confirmability was performed by examining all interview transcripts and analysis tables to determine the theme, while dependability was used to assess the process quality. Conversely, transferability was carried out by writing a research report that was detailed, clear, systematic and easy to understand in order for readers to obtain a clear picture of mothers' experiences. Moreover, authenticity focused on the extent to which researchers were able to demonstrate the reality and genuineness of a participant's life experience.

\section{Ethical consideration}

This study was approved by the Health Research Ethics Commission, Faculty of Nursing, Universitas Sumatera Utara, No. $1416 / \mathrm{IV} / \mathrm{SP} / 2018$, and the consent of respondents was obtained via an informed consent form.

\section{Results}

\section{Characteristic of participant}

This is shown in Table 1.

\begin{tabular}{|l|l|l|}
\hline \multicolumn{2}{|l|}{ Table 1. Characteristic of participant in this study ( $=10)$} \\
\hline Characteristic & $\begin{array}{l}\text { Absolute fre- } \\
\text { quency }(\boldsymbol{n})\end{array}$ & $\begin{array}{l}\text { Relative fre- } \\
\text { quency (\%) }\end{array}$ \\
\hline Age & & 50 \\
$40-50$ years old & 5 & 50 \\
50-60 years old & 5 & \\
\hline Graduated & & 20 \\
elementary school & 2 & 30 \\
junior high school & 3 & 50 \\
senior high school & 5 & \\
\hline Religion & & 90 \\
Moslem & 9 & 10 \\
Christian & 1 & \\
\hline
\end{tabular}




\begin{tabular}{|}
\hline \multicolumn{3}{|l|}{ Table 1. Characteristic of participant in this study ( $=10)$} \\
\hline Characteristic & $\begin{array}{l}\text { Absolute fre- } \\
\text { quency }(\boldsymbol{n})\end{array}$ & $\begin{array}{l}\text { Relative fre- } \\
\text { quency (\%) }\end{array}$ \\
\hline Ethnic & & \\
$\quad$ Bataknese & 4 & 40 \\
$\quad$ Malaynese & 2 & 20 \\
Javanese & 4 & 40 \\
\hline Occupational & & \\
$\quad$ housewife & 9 & 90 \\
civil servant & 1 & 10 \\
\hline
\end{tabular}

Based on Table 1, there are no differences in proportion between the ages of $40-50$ years and $50-60$ years, and most mothers were graduates of senior high schools (50\%), and a majority was of Moslem religion (90\%). Furthermore, the ethnicity was of similar proportion between the Bataknese and Javanese at $40 \%$, while the mothers' occupation was mostly housewife at $85.70 \%$.

The results identified five themes related to the experiences of mothers of children with Down syndrome, including: 1) having an emotional experience; 2 ) accepting the child's situation; 3 ) meeting the needs of children; 4) experiencing obstacles in caring for children; and 5) expectations of mothers.

\section{Having an emotional experience}

The participants portrayed very negative emotional experiences, as seen with the hurt after learning about the child's condition. These feelings include sadness, poor expectations, the need for more time and the display of worry. There was also a sense of confusion with a lack of understanding about Down syndrome.

"...I am not sure my child could have something like this..." (P.3)

"...I can accept it at the age of 2 years..." (P.2)

"...Thinking about the future, because we are getting older, and he is becoming bigger. Also, he lacks understanding, in the absence of things he likes, although better comprehension is shown after eating, if all that matters..."(P.6)

"...At first I didn't know if my child had Down syndrome. In the last few years, I just found out that my child has Down syndrome" (P.8)

Some participants felt positive emotions, which emerges from being a woman based on instincts as a mother. In addition, there was also a feeling of persistent gratitude and fortune in providing care for the affected child.

"...I was still grateful even though my child has Down syndrome but he was still given advantages by God..." (P.5)

"...Despite the problem of treatment, I thank God there is always and only fortune for my child..." (P.2)

\section{Accepting the child's condition}

Participants tend to accept the condition with patience and sincerity, despite the initial refusal at first, on learning about the child's Down syndrome.

"...At first, I refused, hence it is necessary to be patient if you have kids like this at all time..." (P.5)

"...yes, he is my child, I must be sincere. Therefore, if you acclaim that God gave you, that's right, you are being sincere..." (P.2)

\section{Meeting the needs of children}

Participants realize the abnormality in child development, hence the need for special attention from parents, especially mothers. This is often met through medical care, love and supervision,

"...Indeed, my attention is focused on him, which is greater than to my other child..." (P.3)

"...This special need makes me keep watch and never let go..." (P.10)
"...He often falls sick and is then taken to obtain an alternative treatment, including massage..." (P.7)

Mothers make efforts to meet the child's educational needs, as they generally have a right to attend school at a certain age. Mothers also serve as role models by teaching methods to fulfill basic personal needs.

"...When he was five years old, I took him to school, where his aunt taught at the kindergarten level..." (P.3)

"...He complies, as long as we have taught him two or three times. Hence, when you give an instruction like take a bath later, he can understand and practice it again..." (P.7)

\section{Experiencing obstacles in caring for children}

Caring for children with special needs is a struggle, as the participants expressed difficulties, including fatigue, as they sometimes feel ostracized by the surrounding environment.

"...When tired from my child's inability to understand quickIy, we tell him, and he also seems to not comprehend..." (P.5)

"...I think their attitude is different from mine because of my child's condition. This is because if I pass in front of their house, they immediately close the door..."

Difficulties felt in providing care are obtained both from the environment and from the affected children, especially those that are more active.

"...Indeed, when he is more active, we become upset..." (P.1)

"...Sometimes he makes me angry when demonstrating high activity..." (P.9).

\section{Expectations of mothers}

A child with Down syndrome is very dependent on others, especially on the mother. Moreover, some participants share in the hopes of children becoming independent, especially after the mother's demise.

"...Well, it is hoped that he attains independence, gets along and makes friends. Also, I anticipate that he becomes clever, which is not possible..." (P.5)

"...yes, I hope that he can be independent..." (P.10).

In addition, another desire expressed by participants was for the child with Down syndrome to become smart and healthy. This is because of the fact that the affected individuals are more prone to diseases, resulting from a relatively lower immune system.

"...The most important thing is my child's future, despite the fact that he is a fool. However, he can go to school, hence I'm very happy. This ensures consistent progress, even though he is not smart and his brain is driven to think..."

"...l hope he is healthy..." (P.3)

"...I hope he can read, write and understand, that's all..." (P.7).

\section{Discussion}

Emotional experience encompasses the mother's first response as a parent towards accepting the condition of a child born with Down syndrome. This was often negative and sad after diagnosis, featuring disappointment, poor expectations, the need for time to accept the condition, confusion, anger and a lack of understanding. This is in line with research conducted by Kortchmar et al., which reported that mothers undergo coping changes from difficulties in accepting the situation, a poor desire to see their baby, anger and the feeling of sadness [20]. Furthermore, the current study showed positive emotional experiences by some participants, based on the absence of burden and the gratitude for strength. This finding is confusing and contradicts the research conducted by Andreyko, which reported on the first emotional response of refusal [21]. Usually, people faced with problems tend to be sad and angry, although a demonstration of positive emotions is advantageous 
for a higher propensity to attain certain achievement. This observation, therefore, needs to be studied further.

The admission process involves dealing with unforeseen circumstances, which is often initiated with rejection or denial. This does not occur quickly, as time is highly important, followed by possible acceptance by the mother, with sincerity and patience in dealing with the child's daily life. In addition, the affected parents place their ward in an important position within the family in order to foster the development of a warm emotional relationship involving the provision of care and affection [7].

Having a child diagnosed with Down syndrome costs the mother a lot of things, especially in the meeting of specific needs. These demands include treatment, both medically and traditional, as well as alternative therapies, because the condition features a variety of problems, especially health disorders. The immune system also tends to be very poor against disease, hence routine health checks are urgently required [22]. Meanwhile, meeting the needs of daily activities involves teaching basic habits, including eating, bathing and dressing, which is often conducted by the mother. In this study, sick children were taken to alternative medicine for massage, and they also attended school like others [23].

When a mother is entrusted with the provision of care to a child, various obstacles would arise, both for normal births and those diagnosed with Down syndrome. In addition, caring for a child with special needs leads to the challenges of fatigue, feeling ostracized and difficulties in dealing with the children at times when high activity is displayed [24]. The level of physical exhaustion is increased in mothers more than fathers as they spend more time looking after the children, especially while going to and from treatment. Mothers also tend to be detested by others due to the child's condition [25].

Every parent wishes the best for their children. This includes the ability to interact properly with normal children and to be smart and independent. In addition, these great expectations are embraced, because the child is the future of the family, including the expectation of success in education and life in general [7].

This study has limitations, which include difficulties in establishing a communication, because the participants often cried during the interview process. This study was implied as a source of information for policymakers in order to identify the correct actions needed to provide care for children with Down syndrome.

\section{Conclusions}

Mothers are a part of the family that plays a very important role in caring for children with Down syndrome, while families also assist in the formation of independence. Therefore, an exploration of mothers' experiences is expected to provide a better understanding of the condition for families and health workers, which is needed in the provision of care and for proper handling.

Source of funding: This work was funded from the authors' own resources.

Conflicts of interest: The authors declare no conflicts of interest.

\section{References}

1. European Commision. Down syndrome in Europe - has the disorder epidemiology changed over the last querter-century? [cited 7.01.2020]. Available from URL: https://ec.europa.eu/jrc/en/news/down-syndrome-europe-has-disorder-epidemiology-changedover-last-quarter-century.

2. De Graaf G, Buckley F, Skotko BG. Estimation of the number of people with Down syndrome in the United States. Genet Med 2017; 19(4): 439-447.

3. CDC. Down syndrome. 2017. [cited 3.01.2020]. Available from URL: https://www.cdc.gov/ncbddd/birthdefects/downsyndrome.html.

4. De Graaf G, Levine SP, Goldstein R, et al. Parents' perceptions of functional abilities in people with Down syndrome. Am J Med Genet Part A 2019; 179(2): 161-176.

5. Huiracocha L, Almeida C, Huiracocha K, et al. Parenting children with Down syndrome: societal influences. J Child Heal Care 2017; 21(4): 488-497.

6. Rezende L, Caromano F, Carvalho S, et al. Functional performance in children with Down syndrome: correlations between social support and the quality of life of caregivers. Arch Curr Res Int 2016; 4(2): 1-11.

7. Cless JD, Nelson Goff BS, Durtschi JA. Hope, coping, and relationship quality in mothers of children with Down syndrome. J Marital Fam Ther 2018; 44(2): 307-322.

8. Lyons R, Brennan S, Carroll C. Exploring parental perspectives of participation in children with Down syndrome. Child Lang Teach Ther 2016; 32: 79-93.

9. Cahyaningtya MD. Pengalaman pencapaian kesehatan mentalibu dari anak berkebutuhan khusus dengan yoga sebagai salah satu upaya pencapaiannya. 2017. Available from URL: https://repository.usd.ac.id/17788/2/139114169 full.pdf (in Indonesian).

10. Rachmawati SN, Masykur AM. Pengalaman ibu yang memiliki anak down syndrome. J Empati 2016; 5(4): $822-830$ (in Indonesian).

11. Alwhaibi RM, Aldugahishem HM. Factors affecting participation in physical activities in Saudi children with Down syndrome: mothers' perspectives. Disabil Rehabil 2019; 41(13): 1524-1535.

12. Ali A, Scior K, Ratti V, et al. Discrimination and other barriers to accessing health care: perspectives of patients with mild and moderate intellectual disability and their carers. PLOS ONE 2013; 8(8): e70855.

13. Huiracocha L, Almeida C, Huiracocha K. Parenting children with Down syndrome: societal influences. J Child Health Care 2017: 21(4); 488-497.

14. Sukeri S, Bakar R, Othman A, et al. Barriers to unmet needs among mothers of children with disabilities in Kelantan, Malaysia: a qualitative study. J Taibah Univ Med Sci 2017; 12(5): 424-429.

15. Riany YE, Cuskelly M, Meredith P. Cultural beliefs about Autism in Indonesia. Int J Dis Dev Edc 2016; 63: 623-640.

16. Mathebane M. The lived experiences of black African mothers following the birth of a child with Down syndrome: implications for indigenisation of social work. Social Work/Maatskaplike Werk 2016; 52(2): 167-187.

17. Ahmed S, Bryant LD, Ahmed M, et al. Experiences of parents with a child with Down syndrome in Pakistan and their views on termination of pregnancy. J Comm Gntic 2013; 4(1): 107-114, doi: 10.1007/s12687-012-0124-y.

18. Gabel SL, Kotel K. Motherhood in the context of normative discourse: birth stories of mothers of children with Down syndrome. J Med Humanit 2018; 39(2): 179-193.

19. Daunhauer LA, Fidler DJ, Will E. School function in students with Down syndrome. Am J Occup Ther 2014; 68(2): 167-176.

20. Kortchmar E, Jesus MCP de, Merighi MAB. Experience of women with a school-age child with Down syndrome TT - Vivencia de mujeres con un hijo con síndrome de down en edad escolar TT - Vivência da mulher com um filho com síndrome de down em idade esco- 
lar. Texto \& Contexto - Enfermagem 2014; 23(1): 13-20. Available from URL: http://www.scielo.br/scielo.php?script=sci_arttext\&pid $=$ S0104-07072014000100013 (in Portugese).

21. Andreyko B. The emotional state of parents in the structure of the stages of the experience of having a child with developmental disabilities. J Educ Cult Soc 2016; 7(2): 150-157.

22. Rafii MS, Kleschevnikov AM, Sawa M, et al. Down syndrome. In: Handbook of clinical neurology Vol. 167, Dekosky ST, Asthana S, eds. Elsevier B.V.; 2019: 321-336. Available from URL: http://dx.doi.org/10.1016/B978-0-12-804766-8.00017-0.

23. Alwhaibi RM, Aldugahishem HM. Factors affecting participation in physical activities in Saudi children with Down syndrome: mothers' perspectives. Disabil Rehabil 2019; 41(13): 1524-1535. Available from URL: https://doi.org/10.1080/09638288.2018.1433241.

24. Cuzzocrea F, Murdaca AM, Costa S, et al. Parental stress, coping strategies and social support in families of children with a disability. Child Care Pract 2016; 22(1): 3-19.

25. Dębska G, Milaniak I, Domańska D, et al. Caregiver burden and the role of social support in the care of children with cystic fibrosis. Fam Med Prim Care Rev 2019; 21(2): 98-103.

Tables: 1

Figures: 0

References: 25

Received: 4.02.2020

Reviewed: 9.02.2020

Accepted: 27.03.2020

Address for correspondence:

Dewi Elizadiani Suza, PhD

Universitas Sumatera Utara

JI. Prof. Maas No. 3 Kampus USU Medan 20155

Indonesia

Tel.: +62 8126064169

E-mail: dewi1@usu.ac.id 